\title{
Pengaruh Model Pembelajaran Kooperatif Tipe Student Team Achievement Divisions (STAD) Berbasis Mind Mapping terhadap Kemampuan Pemahaman Konsep Matematis Peserta Didik di SMP Negeri 232 Jakarta
}

\author{
Eka Yunita Rahayu ${ }^{1, \text { a) }}$, Swida Purwanto ${ }^{2, \text { b) }}$, Meiliasari ${ }^{3, c)}$ \\ ${ }^{123}$ Pendidikan Matematika, FMIPA, Universitas Negeri Jakarta \\ Email: a)eka.yntrhy@gmail.com, ${ }^{\text {b) }}$ swipur1964@gmail.com, ${ }^{\text {c) }}$ meiliasari@unj.ac.id
}

\begin{abstract}
Abstrak
Kemampuan pemahaman konsep matematis adalah kemampuan peserta didik dalam memahami ideide matematika dan menangkap arti dari materi yang telah dipelajari. Kemampuan pemahaman konsep matematis dapat dikembangkan melalui pembelajaran yang berpusat pada peserta didik, salah satunya yaitu model pembelajaran kooperatif tipe STAD berbasis mind mapping. Penelitian ini bertujuan untuk mengetahui apakah model pembelajaran yang diterapkan tersebut memiliki pengaruh terhadap kemampuan pemahaman konsep matematis peserta didik. Metode penelitian yang digunakan adalah quasi experiment. Populasi dalam penelitian ini adalah seluruh peserta didik kelas VII SMPN 232 Jakarta. Teknik pengambilan sampel menggunakan purposive sampling dan cluster random sampling, sehingga terpilih dua kelas untuk penelitian, yaitu kelas VII-A sebagai kelas eksperimen yang menerapkan model pembelajaran kooperatif tipe STAD berbasis mind mapping dan kelas VII-C sebagai kelas kontrol yang menerapkan model pembelajaran konvensional. Instrumen penelitian yang digunakan adalah instrumen tes kemampuan pemahaman konsep matematis berupa 5 butir soal uraian. Berdasarkan uji analisis data menggunakan uji-t dengan taraf signifikansi $\alpha=0,05$, diperoleh nilai $t_{\text {hitung }}=2,4841>t_{\text {tabel }}=1,6690$, sehingga $H_{0}$ ditolak. Artinya rata-rata kemampuan pemahaman konsep matematis peserta didik kelas eksperimen lebih tinggi dibandingkan peserta didik kelas kontrol. Sehingga dapat disimpulkan bahwa penerapan model pembelajaran kooperatif tipe STAD berbasis mind mapping memberikan pengaruh yang signifikan terhadap kemampuan pemahaman konsep matematis peserta didik.
\end{abstract}

Kata kunci: model pembelajaran kooperatif tipe STAD, mind mapping, kemampuan pemahaman konsep matematis.

\section{PENDAHULUAN}

Pendidikan merupakan kebutuhan dasar setiap manusia untuk menjamin keberlangsungan hidupnya agar menjadi lebih baik. Pendidikan merupakan sumber daya insani yang sepatutnya mendapat perhatian terus menerus dalam upaya peningkatan mutu (Bermawi dan Fauziah, 2016:63). Peningkatan mutu pendidikan berarti pula meningkatkan kualitas sumber daya manusia (Muhardi, 2004:490). Untuk itu perlu dilakukan pembaruan dalam bidang pendidikan dari waktu ke waktu tanpa henti.

Salah satu tempat untuk mendapatkan pendidikan diantaranya adalah sekolah. Sekolah adalah sebuah lembaga pendidikan formal yang dirancang untuk pengajaran peserta didik di bawah pengawasan guru (Lestari, Sugiono dan Yuniarti, 2015:166). Salah satu mata pelajaran yang diajarkan di sekolah adalah matematika. Matematika merupakan ilmu pengetahuan dasar yang diajarkan pada setiap jenjang pendidikan baik SD, SMP, maupun SMA. Fadillah, Suyono dan Triyanto (2018:112) menyatakan bahwa matematika merupakan ilmu dasar yang mampu 
mendukung ilmu lain dan sarana berpikir ilmiah yang diharapkan dapat dipelajari dan dikuasai dengan baik oleh peserta didik.

Kemampuan pemahaman konsep matematis merupakan aspek penting yang harus dimiliki oleh peserta didik dalam proses pembelajaran matematika (Permendiknas, 2006:346). Hal tersebut didukung oleh pendapat Hendriana, Rohaeti, dan Sumarmo (2018:3) bahwa pemahaman konsep matematis sangat mendukung pada pengembangan kemampuan matematis peserta didik lainnya, yaitu kemampuan mengetahui, mengaplikasikan dalam masalah, penalaran, komunikasi, koneksi, representasi, berpikir kritis dan berpikir kreatif matematis.

Kemampuan pemahaman konsep matematis adalah suatu kompetensi dasar dalam belajar matematika yang meliputi kemampuan peserta didik dalam menyerap suatu materi, mengingat rumus dan konsep matematika, serta menerapkannya dalam kasus sederhana atau serupa, memperkirakan kebenaran suatu pernyataan, dan menerapkan rumus dan teorema dalam penyelesaian masalah (Hendriana, Rohaeti, dan Sumarmo, 2018:6). Oleh karena itu, dapat dikatakan bahwa kemampuan pemahaman konsep matematis dalam matematika sangat penting dimiliki oleh peserta didik.

Namun, pada kenyataan yang ada kondisi pembelajaran matematika di Indonesia saat ini masih belum memenuhi harapan yang diinginkan. Kemampuan pemahaman konsep yang dimiliki peserta didik di Indonesia masih rendah. Menurut Annajmi (2016:2) salah satu penyebab kemampuan pemahaman konsep matematis peserta didik yang masih rendah adalah pembelajaran matematika yang dilaksanakan oleh guru di sekolah. Pembelajaran di sekolah saat ini masih didominasi atau berpusat pada guru sebagai pemberi informasi utama, dimana guru secara langsung memberikan penjelasan materi dan konsep-konsep serta contoh-contoh yang berkaitan dengan pembelajaran. Pembelajaran yang berpusat pada guru salah satunya adalah model pembelajaran konvensional. Pembelajaran konvensional merupakan pembelajaran yang berpusat pada guru (teacher centered), artinya selama kegiatan pembelajaran berlangsung guru aktif memberikan uraian materi pelajaran kepada peserta didik, sedangkan peserta didik hanya pasif mendengarkan uraian guru dan hanya menerima, mencatat dan menghafal materi pelajaran (Zulyadaini, 2016:156).

Beberapa penelitian menunjukkan bahwa penerapan model pembelajaran konvensional yang berpusat pada guru kurang dapat mengembangkan pemahaman konsep matematis peserta didik. Seperti penelitian yang dilakukan oleh Hadi dan Kasum (2015:64) yang mengatakan bahwa masalah pokok dalam pembelajaran matematika adalah masih rendahnya pemahaman konsep matematis, hal tersebut disebabkan karena sejauh ini paradigma pembelajaran matematika di sekolah masih didominasi oleh paradigma pembelajaran konvensiona. Selanjutnya Nicke Yulanda, Mukhni dan Fauzan (2014:66) menambahkan bahwa, peserta didik mengalami kesulitan dalam memahami konsep matematis karena disebabkan oleh pembelajaran konvensional yang hanya membiasakan peserta didik menunggu penjelasan dari guru yang mengakibatkan peserta didik tidak memiliki inisiatif untuk melakukan diskusi yang berhubungan dengan materi pembelajaran yang sedang berlangsung.

Berdasarkan hasil wawancara dengan salah satu guru mata pelajaran matematika kelas VII di SMP Negeri 232 Jakarta mengatakan bahwa, kemampuan pemahaman konsep matematis peserta didik di kelas VII masih rendah. Hal ini didukung oleh beberapa fakta lapangan yang ditemui oleh guru saat mengajar. Fakta yang pertama adalah peserta didik lebih sering menghafal rumus dari suatu materi pelajaran. Akan tetapi dari semua rumus yang peserta didik hafalkan tersebut, mayoritas dari mereka tidak mengerti rumus tersebut diperoleh darimana. Fakta yang kedua adalah apabila peserta didik mendapakan soal dengan tipe atau bentuk yang berbeda mereka akan merasa kesulitan dalam mengerjakan soal tersebut.

Hal lain yang dapat memperkuat pernyataan bahwa kemampuan pemahaman konsep matematis peserta didik masih tergolong rendah adalah analisis butir soal esai nomor satu dan tiga yang dilakukan pada soal Penilaian Akhir Semester (PAS) kelas VII semester ganjil tahun ajaran 2018/2019 SMP Negeri 232 Jakarta. Pada soal nomor satu jumlah peserta didik yang menjawab benar hanya berjumlah 9 dari 33 peserta didik, menjawab salah 19 peserta didik dan sisanya tidak menjawab. Selanjutnya, pada soal nomor tiga jumlah peserta didik yang menjawab benar hanya berjumlah 12 dari 33 peserta didik, menjawab salah 18 peserta didik dan sisanya tidak menjawab. 
Jurnal Riset Pendidikan Matematika Jakarta 2020; 2 (2): 50-58

Selain itu, hasil PAS semester ganjil tahun ajaran 2018/2019 pada kelas VII di SMP Negeri 232 Jakarta dari keseluruhan total peserta didik, hanya 30,56\% peserta didik yang mencapai kriteria ketuntasan minimal dari nilai yang telah ditentukan oleh sekolah. Lalu hampir $70 \%$ peserta didik tidak berhasil menjawab soal pada bagian uraian. Berdasarkan hasil wawancara dengan salah satu guru mata pelajaran matematika kelas VII dan hasil PAS semester ganjil tahun ajaran 2018/2019 pada kelas VII disimpulkan bahwa kemampuan pemahaman konsep matematis peserta didik masih rendah. Penyebabnya adalah karena pembelajaran yang terjadi di sekolah masih berpusat pada guru dan peserta didik tidak mengeksplorasi pemahamannya sendiri. Implikasinya peserta didik hanya menghafal rumus saja dari suatu materi pelajaran.

Solusi untuk mengatasi masalah tersebut agar tidak berkelanjutan adalah guru harus bijaksana dalam menentukan suatu model pembelajaran yang sesuai agar dapat menciptakan situasi dan kondisi kelas yang kondusif selama pembelajaran berlangsung, sehingga hal tersebut dapat meningkatkan pemahaman konsep matematis peserta didik (Sariningsih, 2014:152). Selain itu, perlu suatu perubahan paradigma pembelajaran yaitu orientasi pembelajaran yang semula berpusat pada guru beralih berpusat pada peserta didik.

Berdasarkan penelitian yang telah dilakukan, salah satu cara meningkatkan kemampuan pemahaman konsep matematis adalah dengan menggunakan model pembelajaran yang inovatif. Hal ini dikarenakan pembelajaran matematika yang inovatif lebih baik daripada pembelajaran konvensional (Sariningsih, 2014:152). Model pembelajaran inovatif adalah pembelajaran yang berpusat pada peserta didik (Dasor, 2017:89). Model pembelajaran dikatakan berpusat pada peserta didik jika menuntut partisipasi aktif dari peserta didik itu sendiri, seperti pembelajaran yang dilakukan dengan berbagi pengalaman dalam diskusi kelompok dan bekerjasama.

Menurut Adnyasari, Suadnyana dan Wiarta (2013:3) model pembelajaran inovatif yang dimaksud adalah model pembelajaran kooperatif. Model pembelajaran kooperatif dapat meningkatkan kemampuan pemahaman konsep matematis peserta didik karena dalam kegiatan pembelajaran mampu menghadapi kemampuan peserta didik yang beragam, selain itu model pembelajaran kooperatif juga dipandang sebagai cara yang sederhana dan mudah diterapkan oleh guru yang baru menggunakannya. Model pembelajaran kooperatif yang dimaksudkan tersebut adalah model kooperatif tipe Student Team Achievement Divisions (STAD).

Model ini dikembangkan oleh Robert Slavin dan teman-temannya di Universitas John Hopkin yang secara umum dikenal sebagai Kelompok Belajar Siswa (Sharan, 2014:3). Pada model pembelajaran kooperatif tipe STAD, peserta didik dibagi menjadi beberapa kelompok beranggotakan 4-6 orang yang beragaram kemampuan, jenis kelamin dan sukunya. Tahapan-tahapan model pembelajaran kooperatif tipe STAD pada penelitian ini, yaitu: (1) tahap apersepsi (penyampaian tujuan pembelajaran dan motivasi), (2) tahap penyajian materi, (3) tahap kegiatan kelompok (pembentukan kelompok, belajar kelompok dan presentasi kelompok), (4) tahap kegiatan evaluasi (peserta didik mengerjakan kuis secara individu), (5) tahap penghitungan skor (penghitungan skor individu dan kelompok), (6) tahap penghargaan prestasi kelompok, dan tahap penarikan kesimpulan.

Model-model pembelajaran dapat ditunjang dengan suatu teknik pembelajaran. Salah satu teknik yang dapat menunjang model pembelajaran kooperatif tipe STAD adalah mind mapping. Mind mapping akan digunakan saat peserta didik bersama guru membuat kesimpulan selama pembelajaran berlangsung dengan mengisi lembar mind mapping yang sudah disediakan oleh guru. Selain itu, mind mapping akan digunakan pada saat satu pertemuan sebelum pertemuan terakhir, dimana peserta didik diminta untuk membuat rangkuman keseluruhan materi yang sudah dipelajarinya. Hal tersebut dilakukan untuk memudahkan peserta didik dalam memahami dan mengingat keseluruhan materi yang sudah dipelajarinya. Oleh karena itu mind mapping dapat mendukung model pembelajaran kooperatif tipe STAD.

Menurut Buzan (2008:4), mind mapping adalah cara mencatat termudah untuk menempatkan informasi ke dalam otak dan mengambil informasi ke luar otak. Kombinasi warna, gambar, dan cabang- melengkung pada mind mapping lebih merangsang secara visual dibandingkan teknik pencatatan tradisional yang cenderung linear dan satu warna. Dengan demikian mind mapping dalam matematika dapat membuat materi yang saling berhubungan terlihat dan konsep-konsep yang ada 
bisa di ingat dengan lebih baik. Kemudian dalam pengaplikasiannya sangat membantu untuk memahami konsep matematis.

Beberapa penelitian menunjukkan bahwa penerapan model pembelajaran kooperatif tipe STAD berbasis mind mapping dapat mengembangkan pemahaman konsep matematis peserta didik. Seperti penelitian yang dilakukan oleh Abdul Gafur (2015:99) dalam tesisnya disimpulkan bahwa penerapan model pembelajaran kooperatif tipe STAD berbantuan mind mapping mengalami peningkatan pemahaman konsep aritmetika sosial peserta didik kelas VII-A SMPN 1 Watang Pulu dari siklus I ke siklus II sebesar 4,89\%.

Selanjutnya Elly Purwanti dkk. (2018:33) menambahkan dalam penelitiannya bahwa model pembelajaran kooperatif tipe STAD yang dipadu dengan mind mapping dapat meningkatkan hasil pemahaman konsep peserta didik, hal tersebut dibuktikan dengan adanya pingkatan hasil pemahaman konsep pada nilai tes di siklus ke II. Oleh karena itu, model pembelajaran kooperatif tipe STAD berbasis mind mapping dapat mengembangkan pemahaman konsep matematis peserta didik.

Indikator yang digunakan untuk mengukur kemampuan pemahaman konsep matematis peserta didik pada penelitian ini adalah sebagai berikut: (1) menyatakan ulang sebuah konsep, (2) mengklasifikasi objek-objek menurut sifat-sifat tertentu sesuai dengan konsepnya, (3) memberikan contoh dan bukan contoh dari konsep, (4) menyajikan konsep dalam berbagai bentuk representasi matematis, (5) mengembangkan syarat perlu atau syarat cukup suatu konsep, (6) menggunakan dan manfaatkan serta memilih prosedur atau operasi tertentu, dan (7) mengaplikasikan konsep atau algoritma pemecahan masalah.

Berdasarkan uraian tersebut, penelitian ini bertujuan untuk mengetahui apakah penerapan model pembelajaran kooperatif tipe STAD berbasis mind mapping berpengaruh terhadap kemampuan pemahaman konsep matematis peserta didik di SMP Negeri 232 Jakarta.

\section{METODE}

Penelitian ini merupakan penelitian kuantitatif dengan menggunakan metode quasi experiment dan desain posttest-only control group design yang diilustrasikan pada Tabel 1.

TABEL 1. Desain Penelitian

\begin{tabular}{ccc}
\hline Kelas & Perlakuan & Posttest \\
\hline Eksperimen & $\mathrm{X}$ & $\mathrm{Y}$ \\
Kontrol & - & $\mathrm{Y}$ \\
\hline
\end{tabular}

Keterangan:

X : Perlakuan berupa model pembelajaran kooperatif tipe Student Team Achievement Divisions

(STAD) berbasis mind mapping

Y : Posttest kemampuan pemahaman konsep matematis peserta didik

Prosedur dalam penelitian ini terdiri atas empat tahap, yaitu tahap persiapan, tahap pelaksanaan, tahap analisis data, dan tahap penarikan kesimpulan. Populasi target penelitian ini adalah seluruh peserta didik SMP Negeri 232 Jakarta, sedangkan populasi terjangkau penelitian ini adalah peserta didik kelas VII SMP Negeri 232 Jakarta. Teknik pengambilan sampel yang digunakan adalah two stage sampling. Stage pertama menggunakan teknik purposive sampling, yaitu untuk memilih kelaskelas yang diajar oleh guru yang sama dan stage kedua menggunakan teknik cluster random sampling, yaitu untuk menentukan kelas eksperimen dan kelas kontrol dalam penelitian ini.

Data yang diambil untuk penelitian ini adalah hasil Penilaian Akhir Sekolah (PAS) kelas VII semester ganjil tahun ajaran 2018/2019 dan hasil posttest kemampuan pemahaman konsep matematis. Hasil PAS digunakan untuk uji prasyarat analisis data sebelum perlakuan untuk menentukan kelas eksperimen dan kelas kontrol. Adapun hasil posttest kemampuan pemahaman konsep matematis digunakan untuk uji prasyarat analisis data setelah perlakuan, uji analisis data, dan uji besar pengaruh. Teknik pengumpulan data dilakukan dengan memberikan posttest 
Jurnal Riset Pendidikan Matematika Jakarta 2020; 2 (2): 50-58

kemampuan pemahaman konsep matematis kepada peserta didik kelas eksperimen dan kelas kontrol pada pokok bahasan segiempat dan segitiga.

Teknik analisis data yang digunakan pada penelitian ini adalah uji prasyarat analisis data sebelum perlakuan, uji prasyarat analisis data setelah perlakuan, uji analisis data, dan uji besar pengaruh. Uji prasyarat analisis data sebelum perlakuan terdiri dari uji normalitas menggunakan Uji Liliefors, uji homogenitas menggunakan Uji Bartlett, dan uji kesamaan rata-rata menggunakan Uji ANAVA satu arah. Uji prasyarat analisis data setelah perlakuan terdiri dari uji normalitas menggunakan Uji Liliefors dan uji homogenitas menggunakan Uji Fisher. Uji analisis data dilakukan menggunakan Uji-t dua sampel independen. Kemudian, uji besar pengaruh dilakukan menggunakan Uji Cohen's untuk mengetahui seberapa besar pengaruh signifikan model pembelajaran kooperatif tipe STAD berbasis mind mapping terhadap kemampuan pemahaman konsep matematis peserta didik di SMP Negeri 232 Jakarta.

\section{HASIL DAN PEMBAHASAN}

\section{Uji Prasyarat Analisis Data Sebelum Perlakuan}

Hasil uji normalitas sebelum perlakuan disajikan dalam Tabel 2.

TABEL 2. Hasil Uji Normalitas Sebelum Perlakuan

\begin{tabular}{cccc}
\hline Kelas & $L_{o}$ & $L_{\text {tabel }}$ & Interpretasi \\
\hline VII-A & 0,1027 & 0,1542 & Normal \\
VII-B & 0,1216 & 0,1542 & Normal \\
VII-C & 0,1492 & 0,1542 & Normal \\
\hline
\end{tabular}

Berdasarkan Tabel 2, diketahui bahwa seluruh kelas yang diuji memiliki nilai $L_{o}<L_{\text {tabel }}$, artinya keputusan terima $H_{0}$. Hal ini memberikan kesimpulan bahwa ketiga kelas VIIA, VII-B, dan VII-C tersebut berdistribusi normal.

Hasil uji homogenitas sebelum perlakuan disajikan dalam Tabel 3.

TABEL 3. Hasil Uji Homogenitas Sebelum Perlakuan

\begin{tabular}{ccc}
\hline$X_{\text {hitung }}^{2}$ & $X_{\text {tabel }}^{2}$ & Interpretasi \\
\hline 0,3188 & 5,9915 & Homogen \\
\hline
\end{tabular}

Berdasarkan Tabel. 3, diketahui bahwa nilai $X_{\text {hitung }}^{2}<X_{\text {tabel }}^{2}$, artinya keputusan terima $H_{0}$. Hal ini memberikan kesimpulan bahwa ketiga kelas VII-A, VII-B, dan VII-C tersebut memiliki varians yang sama atau homogen.

Hasil uji kesamaan rata-rata disajikan dalam Tabel 4.

TABEL 4. Hasil Uji Kesamaan Rata-rata

\begin{tabular}{ccc}
\hline$F_{\text {hitung }}$ & $F_{\text {tabel }}$ & Interpretasi \\
\hline 0,8177 & 3,0912 & Rata-rata sama \\
\hline
\end{tabular}

Berdasarkan Tabel 4, diketahui bahwa nilai $F_{\text {hitung }}<F_{\text {tabel }}$, artinya keputusan terima $H_{0}$. Hal ini memberikan kesimpulan bahwa ketiga kelas VII-A, VII-B, dan VII-C tersebut memiliki kesamaan rata-rata. Kemudian, dari tiga kelas tersebut terpilih kelas VII-A sebagai kelas eksperimen, yaitu kelas yang memperoleh perlakuan berupa model pembelajaran kooperatif tipe STAD berbasis mind 
mapping dan kelas VII-C sebagai kelas kontrol, yaitu kelas yang memperoleh perlakuan berupa model pembelajaran konvensional.

\section{Uji Prasyarat Analisis Data Setelah Perlakuan}

Hasil uji normalitas setelah perlakuan disajikan dalam Tabel 5.

TABEL 5. Hasil Uji Normalitas Setelah Perlakuan

\begin{tabular}{cccc}
\hline Kelas & $L_{o}$ & $L_{\text {tabel }}$ & Interpretasi \\
\hline VII-A & 0,0834 & 0,1542 & Normal \\
VII-C & 0,0924 & 0,1542 & Normal \\
\hline
\end{tabular}

Berdasarkan Tabel. 5, diketahui bahwa kedua kelas memiliki nilai $L_{o}<L_{\text {tabel }}$, artinya keputusan terima $H_{0}$. Hal ini memberikan kesimpulam bahwa kedua kelas berdistribusi normal.

Hasil uji homogenitas setelah perlakuan disajikan dalam Tabel 6.

TABEL 6. Hasil Uji Homogenitas Setelah Perlakuan

\begin{tabular}{cccc}
\hline$F_{\text {hitung }}$ Ruas Kiri & $F_{\text {tabel }}$ & $F_{\text {tabel }}$ Ruas Kanan & Interpretasi \\
\hline 0,4939 & 1,1867 & 2,0247 & Homogen \\
\hline
\end{tabular}

Berdasarkan Tabel 6, diketahui bahwa nilai $F_{(0,975)(32,32)}<F_{\text {hitung }}<F_{(0,025)(32,32)}$, artinya keputusan terima $H_{0}$. Hal ini memberikan kesimpulan bahwa kedua kelas tersebut memiliki varians yang sama atau homogen.

\section{Uji Analisis Data}

Hasil uji analisis data disajkan dalam Tabel 7.

TABEL 7. Hasil Uji-t Dua Sampel Independen

\begin{tabular}{cc}
\hline$t_{\text {hitung }}$ & $t_{\text {tabel }}$ \\
\hline 2,4841 & 1,6690 \\
\hline
\end{tabular}

Berdasarkan Tabel 7. diketahui bahwa nilai $t_{\text {hitung }}>t_{\text {tabel }}$, artinya keputusan tolak $H_{0}$. Hal ini memberikan kesimpulan bahwa rata-rata skor tes kemampuan pemahaman konsep matematis peserta didik kelas eksperimen lebih tinggi dibandingkan dengan rata-rata skor tes kemampuan pemahaman konsep matematis peserta didik kelas kontrol.

\section{Uji Besar Pengaruh}

Hasil uji besar pengaruh disajikan dalam Tabel 8.

TABEL 8. Hasil Uji Cohen's

\begin{tabular}{ccc}
\hline$d$ & Kategori & Persentase \\
\hline 0,6116 & Sedang & $73 \%$ \\
\hline
\end{tabular}


Jurnal Riset Pendidikan Matematika Jakarta 2020; 2 (2): 50-58

Berdasarkan Tabel 8. dapat disimpulkan bahwa besar pengaruh yang signifikan dari penerapan model pembelajaran kooperatif tipe STAD berbasis mind mapping termasuk ke dalam kategori sedang dengan persentase sebesar $73 \%$.

\section{Pembahasan}

Rata-rata skor tes kemampuan pemahaman konsep matematis peserta didik pada kelas eksperimen lebih tinggi dari kelas kontrol disebabkan oleh beberapa faktor, yaitu peran guru, peserta didik, suasana belajar, serta model pembelajaran yang digunakan. Peserta didik di kelas eksperimen belajar dengan model pembelajaran kooperatif tipe STAD berbasis mind mapping, sedangkan kelas kontrol belajar dengan model pembelajaran konvensional. Pada penerapannya, kedua kelas tersebut berbeda dalam hal proses melatih kemampuan pemahaman konsep matematis.

Pada kelas eksperimen, pembelajaran menggunakan model pembelajaran kooperatif tipe STAD berbasis mind mapping, dimana pada langkah model pembelajaran tersebut melatih kemampuan pemahaman konsep matematis peserta didik. Salah satunya pada tahap kegiatan kelompok, peserta didik dalam kelompok mengerjakan lembar kerja yang telah disediakan oleh guru, dengan begitu peserta didik dapat mengembangkan kemampuan serta mengungkapkan ide atau gagasan dengan kata-kata secara verbal dan membandingkannya dengan ide-ide dalam anggota kelompoknya. Soalsoal yang diberikan pada lembar kerja juga berdasarkan indikator pemahaman konsep matematis, sehingga peserta didik terlatih dalam mengerjakan soal dan dapat meningkatkan pemahaman konsep matematisnya. Selain itu, peserta didik juga dilatih dalam menyampaikan ulang sebuah konsep saat mempresentasikan hasil lembar kerjanya bersama-sama di depan kelas.

Selanjutnya pada tahap kegiatan evaluasi, peserta didik diuji apakah sudah memahami materi yang telah dijelaskan oleh guru. Oleh karena itu, pada tahap ini ketercapaian indikator pemahaman konsep matematis peserta didik dapat diukur, sehingga pada setiap pertemuannya dapat terlihat perubahan ketercapaian indikator tersebut. Pembelajaran di akhiri dengan kegiatan penarikan kesimpulan, yaitu mengingat lagi apa yang telah dipelajari kemudian peserta didik diminta untuk mengisi lembar mind mapping yang sudah disediakan oleh guru. Hal tersebut dilakukan untuk membentuk pemahaman konsep matematis peserta didik yang telah dipelajari menjadi suatu kesatuan yang utuh.

Berbeda dengan kelas eksperimen, pembelajaran pada kelas kontrol menggunakan model pembelajaran konvensional. Model pembelajaran konvensional yang digunakan yaitu kombinasi antara metode ceramah, tanya jawab, diskusi dan penugasan. Pada model pembelajaran konvensional guru secara langsung menyampaikan materi pembelajaran dan peserta didik memperhatikan dan menulis hal-hal penting yang disampaikan oleh guru. Pembelajaran dilanjutkan dengan memberikan beberapa contoh permasalahan yang berkaitan dengan materi yang dipelajari oleh guru. Langkah berikutnya guru meminta peserta didik untuk mengerjakan latihan soal yang diberikan mengenai materi segiempat dan segitiga namun seringkali langkah tersebut dilewati karena waktu yang terbatas.

Pembelajaran yang dilakukan pada kelas kontrol terlihat sangat kontras dibandingkan pembelajaran pada kelas kesperimen, pada kelas kontrol peran guru sangat dominan sedangkan peserta didik benar-benar menjadi pembelajar pasif sehingga seringkali suasana kelas yang tertib bukan karena peserta didik mengerti, namun karena tidak memahami materi yang diajarkan. Akibatnya peserta didik kurang mengeksplor kemampuannya dalam memahami konsep matematisnya. Peserta didik pada kelas kontrol kurang kompetitif dan seringkali tidak kondusif. Hal ini terlihat ketika peserta didik diberikan soal latihan. Sebagian peserta didik kurang begitu semangat, mereka mengerjakan sambil bermain dengan teman lainnya, sehingga hasil yang didapat tidak maksimal.

Secara umum dari kedua kelas yang diteliti, tampak bahwa model pembelajaran kooperatif tipe STAD berbasis mind mapping membuat peserta didik lebih aktif dalam memahami konsep-konsep yang telah mereka kuasai. Pembelajaran dengan model pembelajaran kooperatif tipe STAD berbasis mind mapping memberikan peluang kepada peserta didik untuk menemukan konsep matematika secara mandiri. 
Berdasarkan pembelajaran yang terjadi pada dua kelas yaitu kelas eksperimen dan kelas kontrol serta pengaruhnya terhadap kemampuan pemahaman konsep matematis, maka wajar jika rata-rata kemampuan pemahaman konsep matematis peserta didik pada kelas eksperimen lebih tinggi dibandingkan kelas kontrol. Oleh karena itu, terbukti terdapat pengaruh yang signifikan dari model pembelajaran kooperatif tipe STAD berbasis mind mapping terhadap kemampuan pemahaman konsep matematis peserta didik SMP Negeri 232 Jakarta pada materi segiempat dan segitiga.

\section{PENUTUP}

\section{Kesimpulan}

Berdasarkan hasil uji analisis data yang telah dilakukan, diketahui bahwa kemampuan pemahaman konsep matematis peserta didik yang belajar dengan menggunakan model pembelajaran kooperatif tipe STAD berbasis mind mapping lebih tinggi dari kemampuan pemahaman konsep matematis peserta didik yang belajar dengan menggunakan model pembelajaran konvensional pada pokok bahasan segiempat dan segitiga. Selain itu, model pembelajaran kooperatif tipe STAD berbasis mind mapping berpengaruh terhadap kemampuan pemahaman konsep matematis peserta didik SMP Negeri 232 Jakarta dengan besar pengaruh 73\% dan tergolong dalam kategori sedang.

\section{UCAPAN TERIMA KASIH}

Dalam penelitian ini banyak pihak yang membantu penulis sehingga dapat menyelesaikan penelitian ini, untuk itu penulis mengucapkan terima kasih kepada: Bapak Drs. Swida Purwanto, M.Pd. dan Ibu Dr. Meiliasari, S.Pd., M.Sc. selaku dosen pembimbing, serta seluruh pihak SMP Negeri 232 Jakarta yang bersedia membantu penulis selama penelitian ini.

\section{REFERENSI}

Adnyasari, I.Gst.A. Dian., I.Ngh.Suadnyana \& I.Wyn.Wiarta. (2013). Pengaruh Model Pembelajaran Kooperatif Tipe STAD Dengan Memanfaatkan Linkungan Sebagai Sumber Belajar Terhadap Hasil Belajar IPA Siswa SD. Jurnal Mimbar PGSD Undiksha, 1(1), -10 .

Annajmi. (2016). Peningkatan Kemampuan Pemahaman Konsep Matematik Siswa SMP Melalui Metode Penemuan Terbimbing Berbantuan Software Geogebra. Journal of Mathematics Education and Science, 2(1), 1 - 10.

Bermawi, Yoserizal \& Tati Fauziah. (2016). Penerapan Pendekatan Saintifik Dalam Pembelajaran Di Sekolah Dasar Aceh Besar. Jurnal Pesona Dasar, 2(4), 63 - 71.

Buzan, Toni. (2008). Buku Pintar Mind Map. Jakarta: PT Gramedia.

Dasor, Yohanes Wendelinus. (2017). Efektivitas Pembelajaran Berbasis Student Centered Learning Dalam Mengatasi Kecemasan Komunikasi. Jurnal Inovasi Pendidikan Dasar, 1(1), 81 - 96.

Fadillah, Desty Ainun Ari., Suyono \& Triyanto. (2018). Eksperimentasi Pendekatan Realistic Mathematic dan Pendekatan Problem Solving Terhadap Kemampuan Pemecahan Masalah Matematika pada Materi Relasi dan Fungsi Ditinjau dari Gaya Kognitif Siswa Kelas VIII SMP Negeri 3 Sukoharjo Tahun Pelajaran 2013/2014. Jurnal Pendidikan Matematika dan Matematika SOLUSI, 2(2), 112 - 119.

Gafur, Abdul. (2015). Penerapan Pembelajaran Kooperatif Tipe STAD Berbantuan Mind Mapping untuk Meningkatkan Pemahaman Konsep Aritmetika Sosial di SMPN 1 Watang Pulu. Tesis. Malang: Universitas Negeri Malang. 
Jurnal Riset Pendidikan Matematika Jakarta 2020; 2 (2): 50-58

Hadi, Sutarto \& Maidatina Umi Kasum. (2015). Pemahaman Konsep Matematika Siswa SMP Melalui Penerapan Model Pembelajaran Kooperatif Tipe Memeriksa Berpasangan (Pair Checks). Jurnal Pendidikan Matematika, 3(1), 59 - 66.

Hendriana, Heris., Euis Eti Rohaeti., \& Utari Sumarmo. (2018). Hard Skills dan Soft Skills Matematik Siswa. Bandung: PT Refika Aditama.

Lestari, Karina Dwi., Sugiono \& Rahmi Yuniarti. (2015). Analisis Tingkat Efisiensi Sekolah Dasar Di Kota Malang Menggunakan Data Envelopment Analysis (DEA). Jurnal Rekayasa dan Manajemen Sistem Industri, 3(1), 166 - 177.

Muhardi. (2004). Kontribusi Pendidikan dalam Meningkatkan Kualitas Bangsa Indonesia. Jurnal Sosial dan Pembangunan, 20(4), 478 - 492.

Permendiknas 2006 No. 22, Standar Isi Untuk Satuan Pendidikan Dasar dan Menengah

Purwanti, Elly., dkk. (2018). Penerapan (STAD) Dipadu Mind Mapping Berbasis Lesson Study Untuk Meningkatkan Motivasi dan Pemahaman Konsep. Jurnal Inovasi Pembelajaran, 4(1), 26 -34 .

Sariningsih, Ratna. (2014). Pendekatan Kontekstual Untuk Meningkatkan Kemampuan Pemahaman Matematis Siswa SMP. Jurnal Ilmiah Program Studi Pendidikan Matematika, 3(2), 150 - 163.

Sharan, Shlomo. (2014). The Handbook of Cooperative Learning : Inovasi Pengajaran dan Pembelajaran Untuk Memacu Keberhasilan Siswa di Kelas. Yogyakarta: Istana Media.

Yulanda, Nicke., Muhkni., \& Ahmad Fauzan. (2014). Pengaruh Model Pembelajaran Kooperatif Tipe Student Teams Achievement Division (STAD) Terhadap Pemahaman Konsep Matematika Siswa Kelas VII SMPN 3 Padang. Jurnal Pendidikan Matematika, 3(1), $\quad 61-67$.

Zulyadaini. (2016). Perbandingan Hasil Belajar Matematika Model Pembelajaran Kooperatif Tipe Coop-Coop dengan Konvensional. Jurnal Ilmiah Universitas Batanghari Jambi, 12(1), 153 158. 